\title{
The effect of corporate social responsibility on performance in Nam Dinh seafood enterprises
}

\author{
Tuan Hung Vua , Hoang Long Tran ${ }^{b}$, Thi Tam Le ${ }^{c^{*}}$ and Hai Anh Nguyen
}

\author{
${ }^{a}$ Institute of Regional Sustainable Development, Vietnam Academy of Social Sciences, Vietnam \\ ${ }^{b}$ University of Economics and Technical Industries, Vietnam \\ cThuyloi University, 175 Tay Son, Dong Da, Ha Noi, Vietnam

CHRONICLE ABSTRACT

\begin{tabular}{l}
\hline Article history: \\
Received: June 142019 \\
Received in revised format: July \\
252019 \\
Accepted: August 4, 2019 \\
Available online: \\
August 4, 2019 \\
\hline Keywords: \\
Corporate social responsibil- \\
ity \\
Operational performance \\
Seafood \\
Nam Dinh \\
Vietnam \\
\hline
\end{tabular}

This article aims at determining the impact of corporate social responsibility (CSR) on the operational performance in Nam Dinh seafood enterprises, Vietnam. To achieve this objective, surveys were conducted on 158 Nam Dinh seafood enterprises and the necessary data were analyzed with Smart PLS 3.0 software. The results show that CSR had positive impact on financial and nonfinancial performance of Nam Dinh seafood enterprises. Non-financial performance includes: Customer loyalty, government support and business reputation. On that basis, some recommendations are made for Nam Dinh seafood enterprises to help these businesses confidently implement CSR for future sustainable development.

ietnam

\section{Introduction}

Fisheries is one of Vietnam's export products which brings about an average turnover of over 7 billion per year to more than 40 worldwide markets (Directorate of Fisheries, 2015). In addition to this achievement, Vietnamese fisheries industry has been dealing with many problems, including the challenges related to environmental pollution; excessive exploitation of aquatic resources; food safety, social security, rights and benefits for employees, which may have bad consequences on the reputation and quality of Vietnamese seafood sold to the world market. Many international customers now demand for the necessity that products must satisfy CSR certification systems such as SA8000, BSCI, COSTCO, SMETA, METRO, WALMART, BAP, ASC, etc. Thus, the implementation of CSR becomes one of the conditions for seafood enterprises to export their products to the world market. In order to create a better competitive advantage and to be capable for sustainable development of export business activities, in addition to economic criteria, businesses need to pay attention to the implementation of social responsibility with stakeholders, especially with employers, suppliers, customers and communities in seafood processing and exporting activities, meeting the standards on social responsibility requested by customers (Turker,

\footnotetext{
* Corresponding author. Tel.: +84 0984537282

E-mail address: lethitam@tlu.edu.vn (T. T. Le) 
2009). However, with the aim of rapid development, Vietnam seafood industry also faces many risks: environmental pollution; serious decline in resources and many exported consignments were returned because of the antibiotic residues in products were larger than permitted. Moreover, many companies do not fulfill their obligations to their employees. These risks are mainly due to subjective reasons, such as the lack of full recognition from companies, the employees, the nonlight management of the state management agency or the less strict implementation of social responsibility by enterprises (Stanaland et al., 2011; Santos \& Brito, 2012).

The purpose of the article is to assess the impact of CSR implementation on the financial and non-financial operational performance of Nam Dinh seafood enterprises. The organization of the article, in addition to the introduction, includes: Overview and literature review, research methodology, research results and conclusions.

\section{Research overview and literature review}

\subsection{Corporate social responsibility}

In the research process by scientific communities, there are many different views about the concept, content as well as the scope of corporate social responsibility (Prado-Lorenzo et al., 2008). For each research, the organizations, businesses and government consider the corporate social responsibility from their own perspectives and aspects, depending on different conditions, characteristics and levels of development. The concept of corporate social responsibility was first given by Bowen in 1953. After that, many authors have also mentioned the concept of social responsibility, for example Davis (1960) in "Iron Law of Responsibility", Mc Guire (1963) in "Business and Society". However, at this time, the concept of corporate social responsibility mentioned and defined was often attached to law and economics.

Corporate social responsibility continues to be mentioned and approached in many different ways. According to Carroll $(1979,1999,2000,2001)$, corporate social responsibility includes society's expectations in terms of economic, legal, ethical and charitable aspects for organizations at a certain time. In 1991, he introduced four types of corporate social responsibility constituting the full concept of corporate social responsibility: the economic, legal, ethical and charitable aspects which are described as a pyramid shown in Fig. 1.

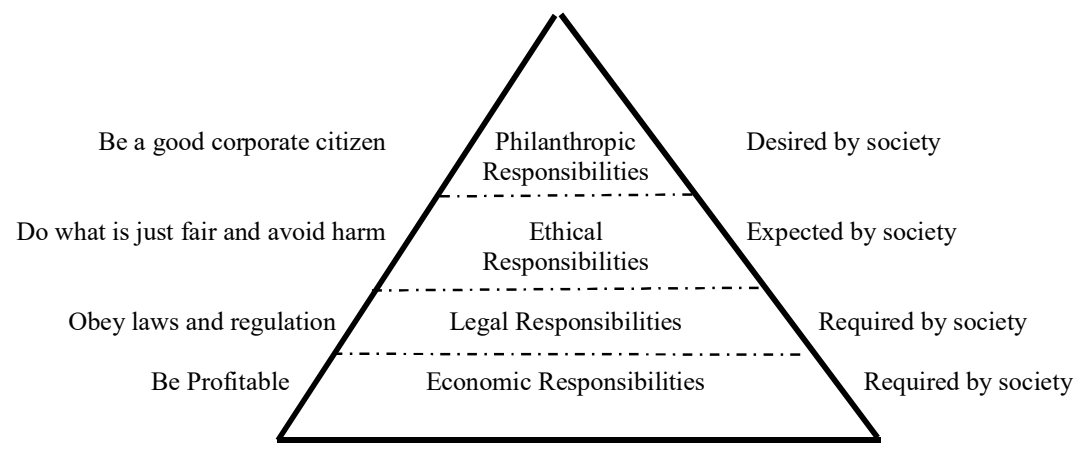

Fig. 1. CSR by Caroll (1991)

Economic Responsibility: Profits maximizing, competition, efficiency and growth are prerequisites as businesses established first because of the entrepreneurs' profit-seeking motivation. Enterprises are also the society's basic economic cells. The remaining responsibilities must be based on the business' awareness of economic responsibility (Mishra \& Suar, 2010; Pratten \& Abdulhamid Mashat, 2009).

Legal responsibility: This is one part of the "contract" between business and society. The state is responsible for bringing social and moral rules into legal documents so that businesses pursue their economic goals within that framework in a fair way and meet the basic norms and values expected by the society. 
Ethical responsibilities: are rules, values accepted by society but have not been included in legal documents, so complying with the law is only considered to meet the minimum requirements and standards that society set out. Enterprises also need to fulfil commitments beyond the laws. Ethical responsibility is voluntary, but is the center part of corporate social responsibility.

Charitable responsibility: is the businesses' behaviors beyond the society's expectations. The difference between charitable responsibility and ethical one is that the business is completely voluntary. If businesses do not fulfil social responsibility to this extent, they are still considered to meet the standards as the society's expectations.

\subsection{CSR and operational performance}

According to Hasan et al. (2018), it is noted that there have been many studies on corporate social responsibility and operational performance, but a few studies have mentioned the impact of corporate social responsibility on different related groups, leading to business benefits that related groups respond in return to businesses on implementing corporate social responsibility. In a study by Weber's (2008), an overall diagram allowing managers to assess how cases of implementing social responsibility actions affect the company's benefit values was illustrated in Fig. 2. In this approach, it is possible to increase the effectiveness of participation in corporate social responsibility practices and support to make suitable decision in this area.

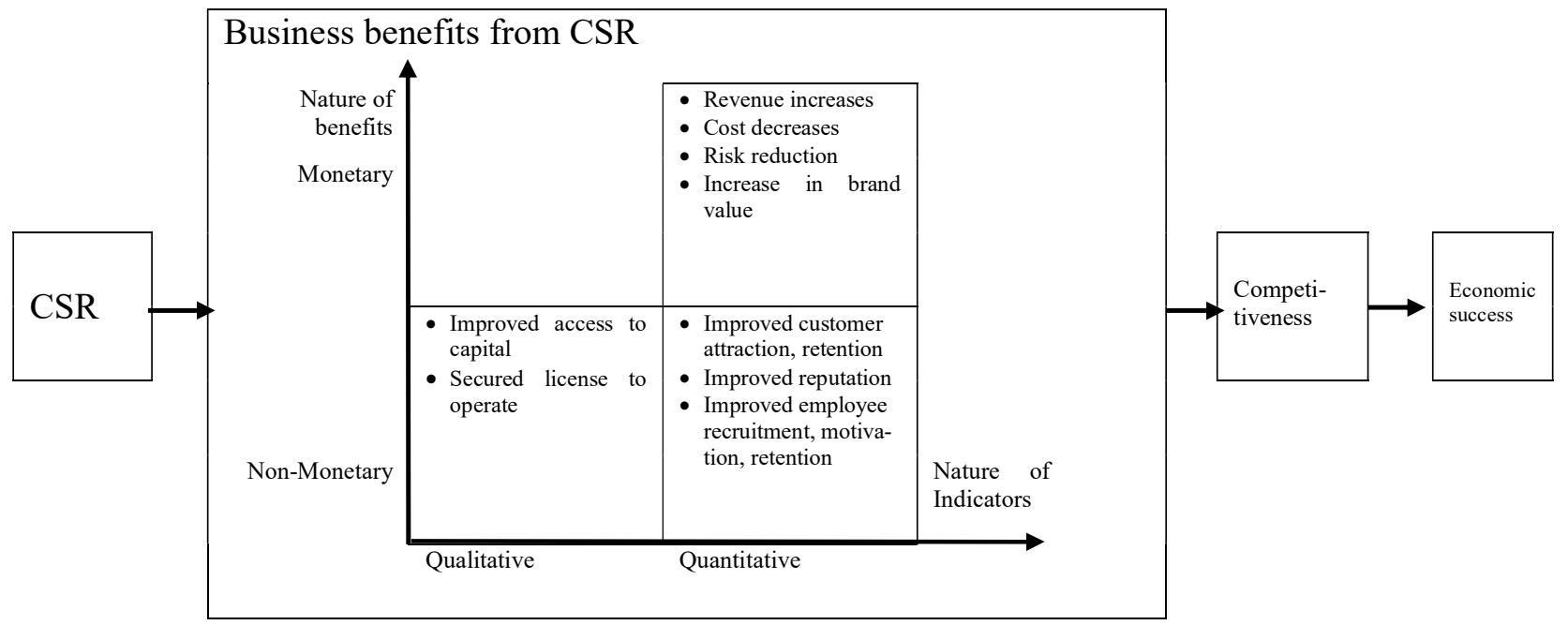

Fig. 2. Social responsibility's benefits characteristics and nature diagram by Weber's (2008)

Corporate social responsibility contributes to the adjustment of business managing quality of business entities (Weber, 2008): Corporate social responsibility is also businessmen's moral commitment about contributions to socio-economic development by improving the workforce and their families' lives, and it brings benefits to the community and society as well. Therefrom, enterprises demonstrate business quality through corporate social responsibility will have more opportunities to cooperate with potential partners, improve capital access opportunities and conditions for upgrading business, ensure competitive advantage and stability for production. Corporate social responsibility makes contributions to accumulating and increasing enterprise's achievements (Weber, 2008; Luo, 2006; Makni \& Bellavance, 2009).

The research is based on measuring the relationship between corporate social responsibility and business's operational performance. Hence, the relationship, firstly, is the relationship between social responsibility and operational performance mentioned from direct to indirect relationship. According to Caroll (2000), studying the relationship between social responsibility fulfilment and business's operational performance obtains the most effective result through stakeholders (Harrison \& Wicks, 2013). 
A study by Lee and Jung (2016) shows that there was a positive relationship between corporate social responsibility implementation and sales. This relationship is reconfirmed by extensive research in the case of large-sized enterprises (Aras et al., 2010; Murillo \& Lozano, 2006), however, there have not been many studies on medium - sized, small - sized and super small - sized businesses. Meanwhile, in contrast with the results by López et al. (2007), when considering financial results: financial activities have negative effects when implementing social responsibility. McGuire $(1963,1988)$ found a relationship which was stronger than positive and emphasized the differences as well as the complex relationships between many components of corporate social responsibility and business's operational performance, specifically, that was the business's reputation, customer/employees' loyalty, and capital access. In addition, it is highly emphasized that the strategies on social responsibility cannot be sustainable in the enterprise without a certain profit. Hasan et al. (2018) also found that, if enterprises do not fulfil their social responsibilities, there will be a remarkable reduction in their operational performance. Research by McWilliams. and Siegel (2000) indicates that businesses that ignore activities to fulfil their social responsibilities may be boycotted, then reputation is destroyed and efficiency is reduced. These studies have not proved whether the implementation of social responsibility will result in an increase in business's operational performance, but it proves the opposite reflection, which means that if the business fulfil social responsibility, it is still uncertain that the operational performance will increase. But if the business does not implement social responsibility activities, then the business's operational performance will decrease.

\section{Research methodology}

\subsection{Background and research sample}

Nam Dinh is a coastal plain province in the southernmost region of the Red and Thai Binh rivers delta, with a total nature area of $1,651.42 \mathrm{~km}^{2}$, accounting for $13.2 \%$ of the Northern Delta area. The province's administrative units include Nam Dinh city and 9 districts with 194 communes, 20 wards and 15 towns. In Nam Dinh, there are many rivers, lakes, lagoons and canals as well as a long coastline with abundant sea resources. People here are familiar with sea products, so seafood, from a traditional industry has rapidly developed into one of the key economic sectors of the province, greatly contributing to economic growth and improving people's lives. Processing is the final stage in the value chain of fisheries sector, contributing to the improvement of fishery products value before delivering to the market. The processed seafood products not only serve domestic consumption needs but also helps export, bringing about a remarkable amount of foreign currency to the province and the country. The ups and downs of this industry are always associated with the general development of the economy, especially the economic development of the country. The research sample is seafood enterprises in Nam Dinh, 180 survey questionnaires were sent to 180 seafood enterprises, with 169 questionnaires collected, after classifying, 158 questionnaires were valid to be used for analysis.

\subsection{Research models}

Fig. 3 demonstrates the structure of the proposed model of this survey.

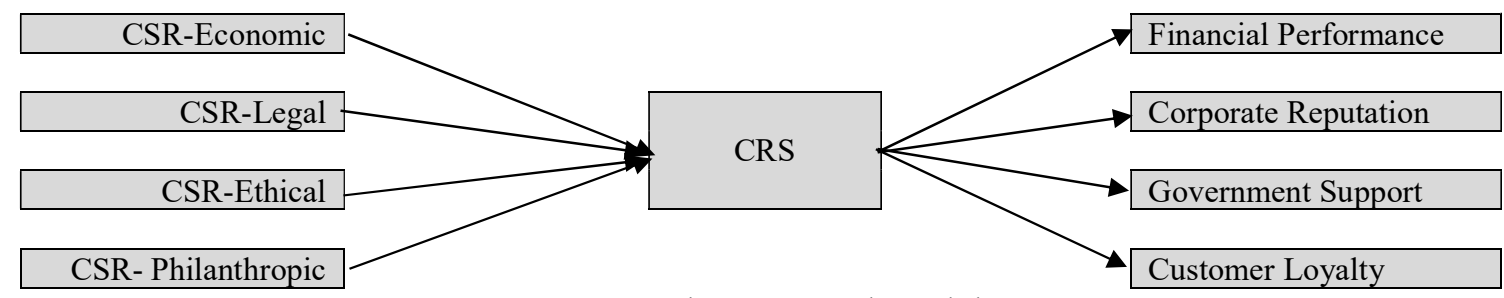

Fig. 3. The proposed model

In the above research model: 
Corporate social responsibility are the business's CSR activities and policies, measured based on the pyramid model of Carol (1991). CSR is measured by 5 - point Likert scale from 1 - no CSR activity to 5 - available and well - done.

Businesses' operational performance consists of enterprises' financial performance measured by ROA, ROE, ROI compared to the average level of Nam Dinh province in the last 3 years by 5 - point Likert scale from 1 - Much lower to 5 - Much higher.

Non-financial performance is measured by three aspects: customer loyalty, government trust and business reputation, in which, customer loyalty, government trust and business reputation are developed from Phan's study (2019). The scales are measured by the 5-point Likert scale from 1 - Strongly disagree to 5 - Strongly agree.

Research hypotheses:

$\mathrm{H}_{1}$ : CSR has positive effect on financial performance.

$\mathrm{H}_{2}$ : CSR has positive effect on non - financial performance of Nam Dinh seafood enterprises, including: customer loyalty, government trust and business reputation.

\subsection{Method for analysis}

To analyze the data, first, the reliability of the scale is tested with SPSS 22 software to determine the Cronbach Alpha coefficients and the correlation of the total variables, scales with Cronbach Alpha coefficient greater than 0.7 and total variables correlation higher than 0.3 are accepted for further analysis (Chin, 1998; Henseler et al. 2009). When all factors and scales are satisfied and appropriate to put into hypothesis testing, the second part of the analysis based on the software of Smart PLS 3.0 is used to conduct PLS and bootstrap analysis to test the research hypotheses (Hair et al., 2014, 2017).

\section{Research results}

Table 1

Construct Reliability and Validity

\begin{tabular}{lcccc}
\hline & Cronbach's Alpha & rho_A & Composite Reliability & Average Variance Extracted (AVE) \\
\hline CSR & 0.920 & 0.922 & 0.920 & 0.697 \\
CSR_DD & 0.911 & 0.912 & 0.911 & 0.672 \\
CSR_KT & 0.872 & 0.884 & 0.872 & 0.696 \\
CSR_PL & 0.762 & 0.887 & 0.784 & 0.738 \\
CSR_TT & 0.928 & 0.936 & 0.925 & 0.677 \\
Corporate reputation & 0.838 & 0.901 & 0.846 & 0.656 \\
Financial performance & 0.949 & 0.953 & 0.948 & 0.650 \\
Government support & 0.932 & 0.935 & 0.932 & 0.776 \\
Customer loyalty & 0.945 & 0.947 & 0.945 & 0.776 \\
\hline
\end{tabular}

The table of composite reliability evaluation shows that all scales and latent variables satisfy conditions for further analysis.

Table 2

Discriminant Validity Fornell-Larcker (Fornell \& Larcker, 1981) Criterion

\begin{tabular}{|c|c|c|c|c|c|c|c|c|c|}
\hline & CSR & CSR_DD & CSR_KT & CSR_PL & CSR_TT & $\begin{array}{l}\text { Corporate } \\
\text { reputation }\end{array}$ & $\begin{array}{l}\text { Financial } \\
\text { performance }\end{array}$ & $\begin{array}{l}\text { Government } \\
\text { support }\end{array}$ & $\begin{array}{l}\text { Customer } \\
\text { loyalty }\end{array}$ \\
\hline CSR & 0.835 & & & & & & & & \\
\hline CSR_DD & 0.351 & 0.820 & & & & & & & \\
\hline CSR_KT & 0.231 & 0.060 & 0.834 & & & & & & \\
\hline CSR_PL & 0.083 & 0.026 & 0.022 & 0.859 & & & & & \\
\hline CSR_TT & 0.165 & 0.184 & 0.288 & 0.036 & 0.823 & & & & \\
\hline Corporate reputation & 0.222 & 0.177 & 0.212 & 0.196 & 0.216 & 0.810 & & & \\
\hline Financial performance & 0.313 & 0.392 & 0.388 & 0.401 & 0.396 & 0.269 & 0.806 & & \\
\hline Government support & 0.380 & 0.172 & 0.390 & 0.313 & 0.297 & 0.229 & 0.321 & 0.881 & \\
\hline Customer loyalty & 0.237 & 0.163 & 0.168 & 0.176 & 0.204 & 0.340 & 0.335 & 0.271 & 0.881 \\
\hline
\end{tabular}


The parameters smaller than the square root of AVE indicate that the data are satisfactory for the next analysis. Next, the research hypotheses test is conducted with PLS - SEM model in Smart PLS 3.0 software. The results are as follows:

Bootstrap results from Smart PLS 3.0 software:

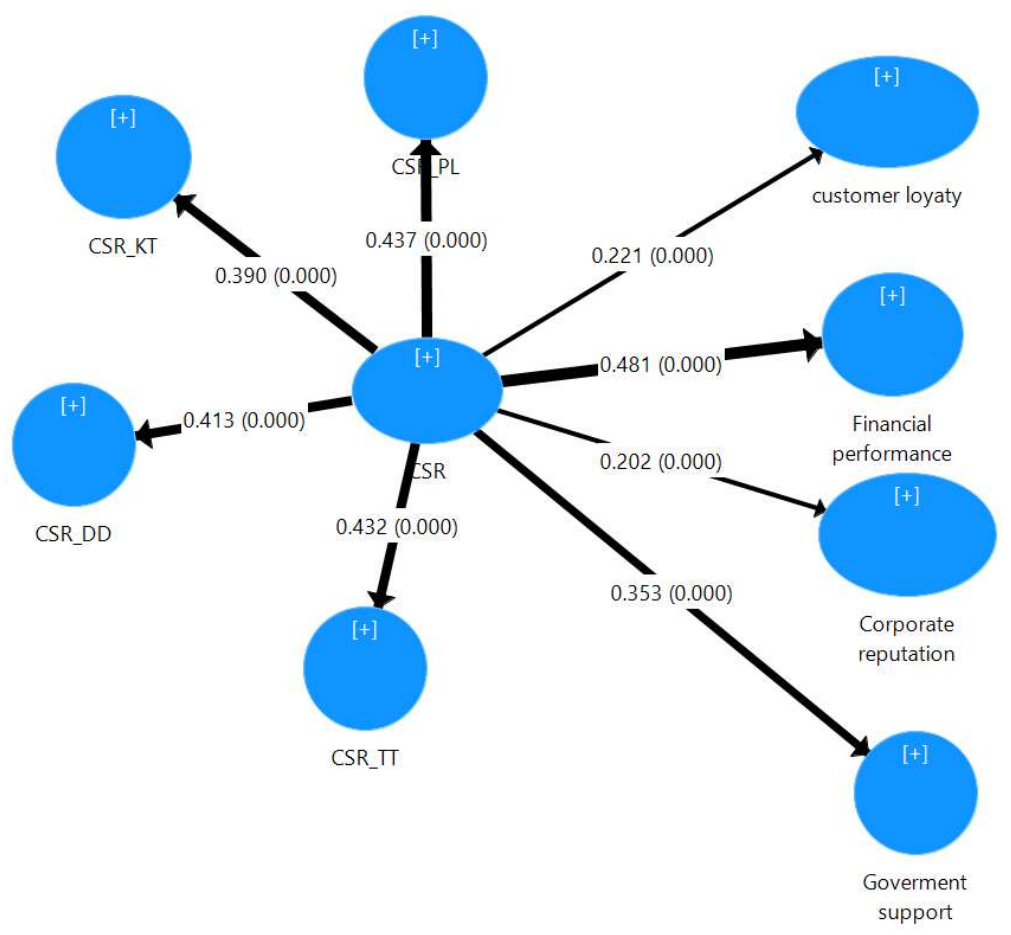

Fig. 4. Hypothesis test results

The hypothesis test results are as follows:

\section{Table 3}

Hypothesis test results

\begin{tabular}{lccccc}
\hline & Original Sample $(\mathrm{O})$ & Sample Mean $(\mathrm{M})$ & Standard Deviation (STDEV) & T Statistics $(|\mathrm{O} / \mathrm{STDEV}|)$ & P Values \\
\hline $\mathrm{CSR} \rightarrow$ CSR_DD & 0.413 & 0.418 & 0.045 & 9.137 & 0.000 \\
$\mathrm{CSR} \rightarrow$ CSR_KT & 0.390 & 0.396 & 0.045 & 8.686 & 0.000 \\
CSR $\rightarrow$ CSR_PL & 0.437 & 0.444 & 0.042 & 10.392 & 0.000 \\
$\mathrm{CSR} \rightarrow$ CSR_TT & 0.432 & 0.438 & 0.041 & 10.431 & 0.000 \\
$\mathrm{CSR} \rightarrow$ Corporate reputation & 0.202 & 0.208 & 0.045 & 4.522 & 0.000 \\
$\mathrm{CSR} \rightarrow$ Financial performance & 0.481 & 0.484 & 0.044 & 10.881 & 0.000 \\
$\mathrm{CSR} \rightarrow$ Government support & 0.353 & 0.355 & 0.051 & 6.943 & 0.000 \\
CSR $\rightarrow$ customer loyalty & 0.221 & 0.224 & 0.057 & 3.871 & 0.000 \\
\hline
\end{tabular}

It can be clearly seen from the results in Fig. 4 and Table 3 that both hypotheses $\mathrm{H}_{1}$ and $\mathrm{H}_{2}$ are supported. CSR has a strong impact on the financial performance of Nam Dinh seafood enterprises, with a coefficient of impact of 0.481 at the significance level $1 \%(\mathrm{P}-\mathrm{value}=0.000)$. Next, CSR has a quite strong positive impact on the government's trust with an impact coefficient of 0.353 at the significance level $1 \%$ $(\mathrm{P}$-value $=0.000)$. CSR affects customer loyalty and business reputation at nearly the same level of 0.221 and 0.202 and at a significant level of $1 \%(\mathrm{P}$-value $=0.000)$. It can be concluded from this result that the 
more CSR implementation Nam Dinh seafood enterprises fulfil, the better the enterprises' operational performance is through the improvement of financial and non-financial performance.

\section{Conclusion}

The analysis on social responsibility of Vietnamese seafood processing enterprises for export to stakeholders shows that there have been a number of limitations in the awareness and implementation of corporate social responsibility, originating from both objective aspects, that is the state's unreasonable management activities, and subjective aspects such as the enterprises' business activities. The research has suggested that, in order to improve business performance, it is necessary to focus on financial performance (increase profitability); improve operational performance in stages of production process so that the output products could be able to meet the market's needs, which helps the businesses survive, develop in long-term, bring benefits to the businesses' owners and other stakeholders. However, for the trend of sustainable development, enterprises in general and Nam Dinh seafood enterprises in particular need to concentrate on implementing social responsibilities through solutions such as: Invest in modern production lines, complete waste treatment systems, prioritize the use of clean and safe technologies, ensuring human rights and working conditions for employees, etc.

The research results have been suggested by many researchers in different contexts, for example Hasan et al. (2019), Aras et al. (2010), Mirsha and Suar (2010). It is proved that implementing CSR will improve the business's performance. Therefore, Nam Dinh seafood enterprises can confidently implement CSR to achieve the objective of sustainable development.

\section{References}

Aras, G., Aybars, A., \& Kutlu, O. (2010). Managing corporate performance: Investigating the relationship between corporate social responsibility and financial performance in emerging markets. International Journal of Productivity and Performance Management, 59(3), 229-254.

Bowen, H. R. (1953). Social Responsibilities of the Businessman: University of Iowa Press.

Carroll. (1979). A three-dimensional conceptual model of corporate performance. The Academy of Management Review, 4(4), 497-505.

Caroll, A. B. (1991). The Pyramid of Corporate Social Responsibility: toward the Moral Management of Organizational Stakeholders Business Horizons. July e August.

Carroll. (1999). Corporate social responsibility: Evolution of a definitional construct (Vol. 38).

Carroll. (2000). Ethical challengs for business in the new millennium : orporate social responsibility and models of management movality. Business Ethics Quately, 10, 33-42.

Carroll. (2003). Business and Society: Ethics and Stakeholder Management. Cengage Learning, Stamford.

Chin, W. W. (1998). The partial least squares approach to structural equation modeling. Modern Methods for Business Research, 295(2), 295-336.

Davis, K. (1960). Can business afford to ignore social responsibilities? California Management Review, 2(3), 70-76.

Fornell, C., \& Larcker, D. F. (1981). Evaluating structural equation with unobservable variables and measurement error. Journal of Marketing Research, 18(1), 39-50.

Galbreath, J. (2010). How does corporate social responsibility benefit firms? Evidence from Australia. European Business Review, 22(4), 411-431.

Guthrie, J. P. (2001). High-involvement work practices, turnover, and productivity: evidence from New Zealand. Academy of Management Journal, 44(1), 180-190.

Hair Jr, J. F., Matthews, L. M., Matthews, R. L., \& Sarstedt, M. (2017). PLS-SEM or CB-SEM: updated guidelines on which method to use. International Journal of Multivariate Data Analysis, 1(2), 107123.

Hair J. F. J., H., G. T. M., Ringle, C., \& Sarstedt, M. . (2014). A Primer on Partial Least Squares Structural Equation Modeling (PLS-SEM) (Vol. 46). 
Harrison, J. S., \& Wicks, A. C. (2013). Stakeholder theory, value, and firm performance. Business Ethics Quarterly, 23(1), 97-124.

Hasan, I., Kobeissi, N., Liu, L., \& Wang, H. (2018). Corporate social responsibility and firm financial performance: The mediating role of productivity. Journal of Business Ethics, 149(3), 671-688.

Henseler, J., Ringle, C. M., \& Sinkovics, R. R. (2009). The use of partial least squares path modeling in international marketing. In New challenges to international marketing (pp. 277-319). Emerald Group Publishing Limited.

Lee, S., \& Jung, H. (2016). The effects of corporate social responsibility on profitability: The moderating roles of differentiation and outside investment. Management Decision, 54(6), 1383-1406.

López, M. V., Garcia, A., \& Rodriguez, L. (2007). Sustainable development and corporate performance: A study based on the Dow Jones sustainability index. Journal of Business Ethics, 75(3), 285-300.

Luo, X. (2006). Corporate social responsibility, customer satisfaction, and market value. Journal of Marketing, 70 (4), 1-18.

McWilliams, A. \& Siegel, D. (2000). Corporate social responsibility and financial performance: correlation or misspecification? Strategic Management Journal, 2(5), 603-609.

McGuire, J.W. (1963) Business and Society. McGraw-Hill, New York.

McGuire. (1988). Corporate socail respolnsibility and firm fimamcial performance. Academy of Management Journal, 21, 854-872.

Makni, R. F., C. \& Bellavance, F. (2009). Causality between corporate social performance and financial performance: Evidence from Canadian firms. Journal of Business Ethics, 89, 409-422.

Mishra, S., \& Suar, D. (2010). Does corporate social responsibility influence firm performance of Indian companies?. Journal of Business Ethics, 95(4), 571-601.

Murillo, D., \& Lozano, J. M. (2006). SMEs and CSR: An approach to CSR in their own words. Journal of Business Ethics, 67(3), 227-240.

Prado-Lorenzo, J. M., Gallego-Álvarez, I., García-Sánchez, I. M., \& Rodríguez-Domínguez, L. (2008). Social responsibility in Spain: Practices and motivations in firms. Management Decision, 46(8), 12471271.

Pratten, J. D., \& Abdulhamid Mashat, A. (2009). Corporate social disclosure in Libya. Social Responsibility Journal, 5(3), 311-327.

Phan, T. T. H. (2019) The impact of corporate social responsibility on financial performance in Vietnamese textile enterprises. PhD thesis of National Economics University, Vietnam.

Turker, D. (2009). Measuring corporate social responsibility: A scale development study. Journal of Business Ethics, 85(4), 411-427.

Stanaland, A. J., Lwin, M. O., \& Murphy, P. E. (2011). Consumer perceptions of the antecedents and consequences of corporate social responsibility. Journal of Business Ethics, 102(1), 47-55.

Santos, J. B., \& Brito, L. A. L. (2012). Toward a subjective measurement model for firm performance. BAR-Brazilian Administration Review, 9(SPE), 95-117.

Weber, M. (2008). The business case for corporate social responsibility: A company-level measurement approach for CSR. European Management Journal, 26(4), 247-261.

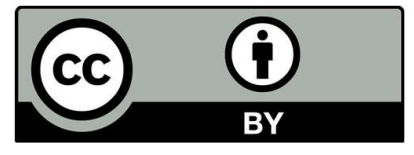

(C) 2020 by the authors; licensee Growing Science, Canada. This is an open access article distributed under the terms and conditions of the Creative Commons Attribution (CCBY) license (http://creativecommons.org/licenses/by/4.0/). 